
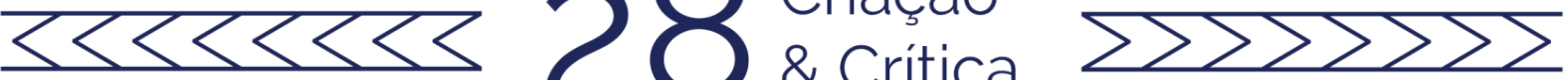

\title{
AS FACES DO NARRADOR EM INFERNO PROVISÓRIO, DE LUIZ RUFFATO
}

Resumo: Partindo da constatação de que a figura do narrador de Inferno provisório (2016), de Luiz Ruffato, tem sido motivo de inquietação tanto para a crítica, quanto para o público leitor em geral, perscrutamos, neste artigo, a identidade desse ser fictício que narra as histórias adunadas no romance. A investigação tem por objetivo revelar a identidade daquele que é responsável por enunciar e modelizar o universo diegético e interpretar os motivos que o levam a utilizar-se de diferentes modos de incursão no mural de histórias. Para o percurso investigativo, foram adotados aportes teóricos que elucidam as categorias do discurso narrativo e que intercruzam história, memória e ficção. As descobertas confirmam a unicidade do narrador do romance e uma estratégia narrativa que não só amplia, mas também subverte as formas tradicionais de narrar.

PalAvRAS-CHAVE: Luiz Ruffato, Inferno Provisório, Narrador.

\section{THE FACES OF THE NARRATOR IN INFERNO PROVISÓRIO, BY LUIZ RUFFATO}

ABSTRACT: Based on the assumption that the figure of the narrator of Inferno provisório (2016), by Luiz Ruffato has been a cause of concern for both the critic and the general public, we examined, in this paper, the identity of this fictional being who narrates the stories found in the novel. The purposes focus on revealing the identity of the one who is responsible for the act of enunciating and modeling the diegetic universe and interpreting the reason for the different modes of incursion in the dashboard of stories. For the investigative path, we adopted theoretical contributions that elucidate the categories of narrative discourse and cross over history, memory and fiction. The findings confirm the uniqueness of the novel's narrator and a narrative strategy that not only broadens, but also subverts traditional ways of narrating.

KeYwords: Luiz Ruffato. Inferno Provisório. Narrator.

\section{À guisa de introdução}

Este trabalho versa sobre a figura do narrador do romance Inferno provisório (2016), de Luiz Ruffato. A leitura da obra baliza-se pelo questionamento: Quem narra esse romance que se constitui por trinta e oito histórias, abarca um largo interstício temporal e congrega um copioso número de personagens? Todavia, antes de adentrarmos no cerne desta questão, é indispensável uma recapitulação do processo de construção do projeto Inferno Provisório para contextualizar o objeto de análise e também assinalar uma possível origem da problemática em torno do narrador do romance.

Comecemos pela revelação de Luiz Ruffato no cenário da literatura brasileira contemporânea. A publicação do romance Eles eram muitos cavalos, no ano de 2001, foi

\footnotetext{
1 Docente do quadro efetivo do Instituto Federal de Educação, Ciência e Tecnologia do Mato Grosso (IFMT), onde atua na área de linguagem. Possui Doutorado em Estudos Literários pela Universidade do Estado de Mato Grosso (UNEMAT), concluído em 2020. E-mail: daniele.silva@tga.ifmt.edu.br.
} 

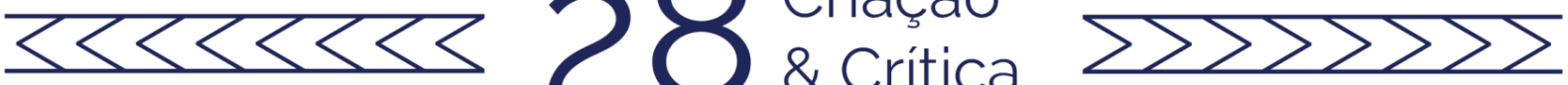

um marco na carreira do escritor. Isto não só pelo sucesso de venda, mas, sobretudo, pela recepção da crítica que o posicionara dentre os romances mais significativos da atualidade. Fatos que despertaram o interesse da então diretora editorial da Record², a quem Luiz Ruffato propôs "um projeto chamado Inferno Provisório composto por cinco volumes, que tentaria contar a história da brutal industrialização do Brasil a partir do ponto de vista dos trabalhadores urbanos" (RUFFATO, 2014, p. 178). O contrato firmado com a editora oportunizou ao escritor a tão sonhada dedicação exclusiva à escrita literária.

O projeto concretizou-se na série Inferno Provisório, a qual se desdobrara em cinco volumes publicados entre 2005 e 2011 - Mamma, son tanto Felice, Volume I (2005); O mundo inimigo, Volume II (2005); Vista parcial da noite, Volume III (2006a); O livro das impossibilidades, Volume IV (2008) e; Domingos sem Deus, Volume V (2011a) -. Em 2016, chegou nas livrarias a obra Inferno provisório, em volume único, publicada pela editora Companhia das Letras. Todavia, a gênese desse projeto remonta a dois livros publicados antes mesmo do romance Eles eram muitos cavalos (2001), os quais funcionaram como experimentação de uma técnica narrativa almejada pelo escritor. São eles: Histórias de remorsos e rancores (1998) e (os sobreviventes) (2000).

Essas obras são os croquis do Inferno Provisório. Nelas, Ruffato experimentou formas que poderiam acomodar um conteúdo definido antes mesmo de iniciar sua labuta na seara da literatura brasileira, qual seja: o cotidiano do trabalhador de classe média baixa, no cenário urbano. Eis a problemática que, segundo o próprio Ruffato, por muito tempo Ihe inquietara: "Como posso escrever sobre a classe média baixa, sobre o proletariado, usando a forma romance, que foi criado para dar uma visão de mundo da burguesia?" (RUFFATO, 2006b). A solução adveio da inspiração numa "tradição-paralela" a do romance burguês, conhecida como "anti-romance". Havendo estudado seu funcionamento, Ruffato lançou-se na escrita de Histórias de remorsos e rancores. Sobre essa incursão, declarou:

[...] O livro tratava do universo proletário, experimentando uma forma de histórias, o que não quer dizer contos. Eu queria ver se aquele tipo de forma poderia ser tomado como um romance. Mas não foi. Era tido como o um livro de contos, o que eu não queria (RUFFATO, 2006b, s/p).

À luz da estética da recepção, é oportuno salientar acerca do peso dos horizontes de expectativas. Sobre o qual, Aguiar e Bordini (1993, p. 83) asseguram que as transferências entre as expectativas do autor e as do leitor instauram a seguinte problemática: "O texto se torna o campo em que os dois horizontes podem identificar-se ou estranhar-se". A questão torna-se mais complexa quando se trata de um escritor que se encontra em plena atividade. Fato que levara Luiz Ruffato a reconhecer que a recusa, por parte do leitor, do status genérico do seu primeiro livro de histórias, implicara na declaração taxonômica do seu segundo livro: "Então resolvi escrever o segundo livro como contos, mas já sabendo que não eram exatamente

2 Trata-se de Luciana Villas-Bôas, ocupante do cargo de diretora editorial da Editora Record de 1995 a 2012. 

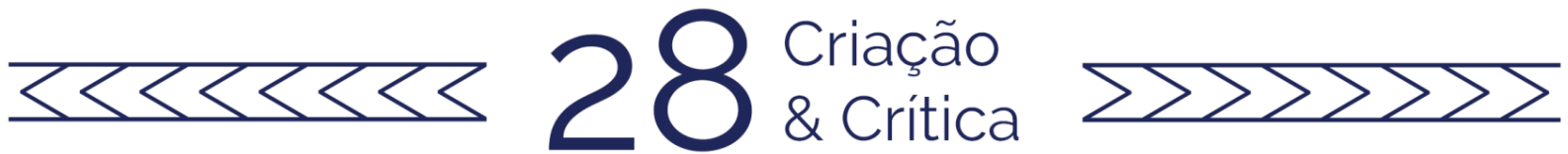

contos. Que eram parte um projeto a longo prazo. Esse livro, que se chamou os sobreviventes [...]" (RUFFATO, 2006b, s/p).

Essa sucinta retomada da origem do projeto literário de Luiz Ruffato não tem por pretensão perscrutar uma determinação genérica às obras. O que se propõe é apresentálas como universos anunciativos e constituintes de Inferno Provisório. Tomando o projeto, seja em seus cinco volumes ou em volume único, à maneira de um sistema planetário de engrenagens, no qual as trinta e oito histórias orbitam entorno da grande épica dos trabalhadores de classe média baixa da segunda metade do século XX, é que seguimos no encalce de pistas que corroborem a identidade do narrador de Inferno provisório (2016).

\section{O universo romanesco no plano enunciativo}

A crítica literária brasileira tem tomado as obras que configuram o universo de Inferno Provisório como romances e as trinta e oito histórias que o constitui, como micronarrativas. Nas fichas catalográficas de todas as obras, a declaração genérica de romances. Quanto ao emprego do termo 'micronarrativa, utilizado para nomear narrativas curtas de ficção, Vieira (2012) destaca sua viabilidade por independer da categorização genérica do texto. Ou seja, por configurar-se pelo seu fenômeno de comunicação com as estruturas narrativas, ainda que estas sejam extremamente reduzidas (VIEIRA, 2012, p. 18).

As histórias que compõem Inferno Provisório podem ser lidas de maneira independente, sem comprometimento algum à coerência narrativa ou à literariedade. Por outro lado, se o projeto for tomado em sua completude, as interdependências entre as histórias tornam-se fundamentais para consistência formal e composicional do romance. É, pois, desta perspectiva que a figura do narrador é apreendida para o esquadrinhamento das informações sobre sua identidade. Em virtude de ser a versão mais atualizada do projeto literário de Ruffato e por conglomerar as fabulações, o volume único é tomado como objeto primordial desta investigação.

Constata-se a problemática em torno do narrador de Inferno provisório pelas divergências na maneira como essa figura tem sido apreendida e referenciada nos discursos acadêmicos. A dubiedade decorre da forma como o romance se concretiza: alternâncias entre planos temporais e espaciais, oscilações nos níveis narrativos, múltiplas perspectivas, mesclas de gêneros e outras experimentações técnicas.

Tem sido comum também as ocorrências em que a identidade do narrador aparece vinculada à determinada história, normalmente referenciada por "micronarrativa". Sem dúvida, tal abordagem, se não resolve, facilita a manipulação das informações que giram em torno dessa entidade cara à narrativa de ficção. Em um recente artigo sobre Inferno provisório, Pellegrini (2020) atribui o ato de enunciação e a configuração do universo diegético a vários narradores. Apesar da leitura crítica apresentada pela estudiosa não se desdobrar sobre a figura do narrador, a declaração da existência de "diferentes narradores" no romance é instigante. As complexidades que envolvem as estratégias de enunciação 

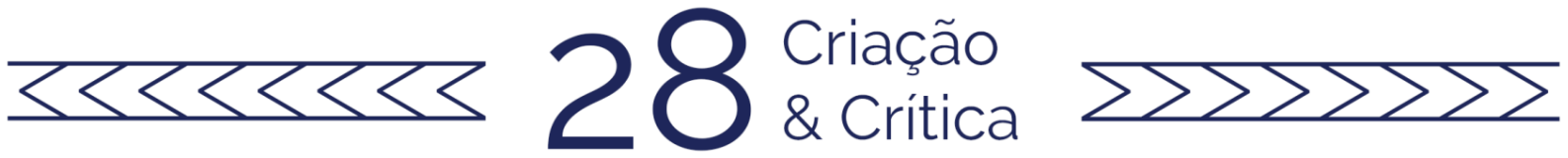

parecem ser potencializadas por Ruffato em Inferno provisório. Todavia, um laborioso trabalho de associação de informações dispersas pela volumosa obra corrobora para 0 reconhecimento de Luís Augusto como o único narrador do romance.

\section{No encalce do narrador}

Para revelar a identidade do narrador de Inferno provisório (2016) é necessária uma varredura, insubordinada à ordem sequencial das histórias ou cronológica dos fatos, com paragens em excertos cruciais. A primeira 'história' do romance, "UMA FÁBULA", narra a formação e o desmanche da família do "Micheletto velho". Personagem que usara, enquanto pôde, da força física e da violência para conduzir os seus. A narrativa tem início com o relato sobre o parto de André, o filho caçula. Todavia, as lembranças não advêm de uma vivência do narrador, mas da parteira: "André, André pequeno, Andrezim, parto difícil, até o último respiro a tia Maria Zoccoli suava ao alembrar [...]" (RUFFATO, 2016, p. 17). Com o substantivo "tia" o narrador não só revela certa empatia para com a parteira, mas também recompõe uma forma de tratamento dispensado pelas crianças aos mais velhos no tempo dos acontecimentos, o qual remonta ao contexto sócio-histórico dos primeiros anos da segunda década do século XX. Além disso, no presente da enunciação, a forma de tratamento denota a condição do narrador enquanto membro daquela comunidade. Atribuídas à parteira, as memórias sobre os nascimentos ganham legitimidade. O que, por sua vez, não as limitam a um pertencimento individual. Maurice Halbwachs, em $A$ memória coletiva (2006), diz que para se lembrar é indispensável a presença de "outros". Presença não necessariamente física, podendo ser também internalizada pelo indivíduo que lembra. Ainda que o narrador não tenha presenciado os partos, as memórias sobre eles também lhes pertencem por ser membro da comunidade. É provável que o narrador os tenha captado por relatos que ouvira de outros, podendo ainda ter sido direcionados a ele ou não. O arcaísmo linguístico "alembra" põe em evidência o vínculo do narrador com sua comunidade. Luís Augusto é capaz de narrar e transmitir a história em virtude do seu papel de ouvinte, exercido com sensibilidade.

Em "OUTRA FÁBULA", a última história do romance, Luís Augusto questiona-se no presente de sua enunciação:

[...] O que era a vinte anos atrás? Uma camisa desembarcando, zonza, na rodoviária da Luz [...] E se recuasse trinta anos? Um menino tímido, [...] nos braços um tabuleiro de alumínio coberto por um alvo pano de prato, pastéis, coxinhas, rissoles, quibes, croquetes e empadinhas [...] o pai, autonomista, [...] na esperança de que pelo menos ele não se convertesse em empregado dos Prata, como o mais velho e a menina, para seu desalento. E candeou-o para as cadeiras noturnas do curso de Contabilidade [...] após uma jornada de faz-tudo na redação d'O Cataguases, estágio sem remuneração que o pai conquistara junto ao redator-chefe do jornal [...] (RUFFATO, 2016, p. 388-389). 

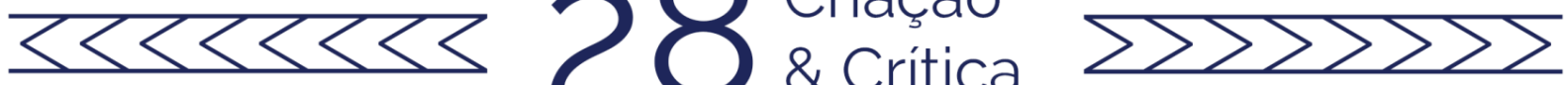

Outra história que prioriza a existência do narrador-personagem é "Era uma vez". Posta ao lado de "OUTRA FÁBULA" as histórias funcionam como verdadeiros painéis da identidade do narrador. Antes de tratarmos das sobreposições de fatos, datas e personagens, retomemos a entrevista que Luiz Ruffato concedera ao programa Entrelinhas, da TV Cultura, na ocasião do lançamento do último volume da sua série literária. Mais precisamente, a passagem em que escritor menciona "Era uma vez" como espécie de porta de acesso à identidade do narrador:

[...] Quando eu escrevi $O$ Livro das impossibilidades e escrevi a história de um personagem chamado Luís Augusto, o Guto, foi naquele momento que eu descobri que ele era o narrador de todas as histórias. Eu não sabia até então. Não que ele sintetize e nesse ponto me afeiçoe. [...] é ele que consegue uma passagem social, se torna jornalista e teria condições de compreender tudo o que passou [...] (RUFFATO, 2011b).

Nessa passagem, Ruffato parece abdicar do posto de autor para se posicionar como leitor do romance. "Era uma vez" é, efetivamente, elementar no desvelamento da identidade do narrador. No entanto, quando diz que nela escrevera a história de Luís Augusto, o autor refere-se a um espaço textual alargado onde são dispensadas maiores atenções às questões históricas e psicológicas do narrador-personagem. Todavia, não é neste microuniverso que surge o narrador. Muito pelo contrário. A existência de Luís Augusto está atrelada a sua enunciação, ou seja, ao momento em que decide narrar. Além disso, a sua própria atuação na diégese pode ser apreendida muito antes da instauração do microuniverso narrativo de "Era uma vez". Em "O segredo", por exemplo, Luís Augusto testemunha o pedido de desligamento de Francisco Pretti do jornal $O$ Cataguases. O professor contribuía com o semanário escrevendo "um artigo, uma crônica, um poema" (RUFFATO, 2016, p. 117). Desvencilhando das perturbações que envolvem o protagonista e atentando aos afazeres de Luís Augusto, na condição de estagiário do jornal, encontramo-lo recepcionando o professor que busca pelo redatorchefe do jornal: "[...] Cumprimentou o adolescente magro e pálido, rosto espinhas e cravos, misto de contínuo e repórter, que, sentado à mesa, revia uma matéria, "O doutor está?" Empurrou a porta, [...] e entrou na sala" (RUFFATO, 2016, p. 126). Assim que o professor deixa a sala do "doutor Divaldo Sobrinho", este chama pelo adolescente:

Luís Augusto! Ô, menino! Vem cá correndo! Dá um pulo na oficina! É urgente! Urgente! Manda trocar o artigo do Professor por esse outro aqui, ó, ah!, meu deus, onde foi que coloquei? [....] Você não viu não? (RUFFATO, 2016, p. 127).

A denúncia da má índole do editor-chefe, que "sempre que podia, atacava impiedoso a oposição, escondido atrás de algum pseudônimo esdrúxulo" (RUFFATO, 2016, p.125), ganha mais nexo quando feita por um ex-estagiário do jornal. Isso porque os fatos são anunciados por um narrador que os constatara no transcorrer dos acontecimentos. 

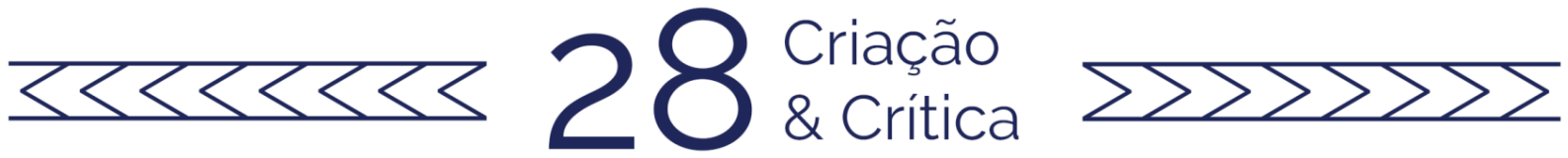

De maneira ainda mais sutil, a identidade do narrador é referida em "O morto", narrativa que se constrói pela simbiose entre ficção e reportagem. A 'história' é dividida em oito blocos textuais separados entre si por duas linhas em branco. A diagramação acomoda uma narrativa que é, por si mesma, incapaz de preencher as lacunas dos acontecimentos. Não bastasse 0 início in media res no primeiro bloco, o discurso entrecortado revela-se a partir de uma conjunção coordenativa e é abruptamente suspenso. Assim, tem-se o início e o fim do primeiro bloco: "e agora desprendeu a ceralustosa que tampava a panela do dente [...] fagulhas ardem no céu limpo de maio, o" (RUFFATO, 2016, p. 179).

Ao tom de uma narrativa policial, o leitor depara-se com os "homens da lei" que, retirados do "bem-bom da delegacia", tentam "mostrar serviço" tocaiando o assassino "na Reta da Saudade" (RUFFATO, 2016, p. 179). A vítima, revelada no desenrolar da narrativa, trata-se do proprietário de um velho circo que desde sua chegada à cidade, estava sendo vigiado pelos 'espias' do delegado.

À primeira estaca fincada, o telefone da delegacia tocou. Imediatamente, o sargento Narciso e o soldado Carneiro montaram no jipe, e, em menos de uma hora, o desconjuntado terno-gravata achava-se perfilado, ansioso, num canto da antessala. Alguma coisa errada?, O delegado quer ter uma palavrinha com o senhor, ministraram (RUFFATO, 2016, p. 182).

O "Homem do Circo", como é tratado pelo narrador, é conduzido à sala do delegado. Esta, por sua vez, é descrita de maneira minuciosa com destaque à estante "abarrotada de compêndios, vade-mécuns, opúsculos, tratados, monografias, memoriais, anuários, brochuras, enciclopédias" (RUFFATO, 2016, p. 182). O acervo bibliográfico não se reduz à "casualidade nua e crua", mas é elevado "ao plano da necessidade", como orienta Lukács (1965, p. 46), ao criticar o estilo descritivo desvinculado da ação épica, ou seja, desligado dos acontecimentos. Nesse sentido, Lukács (1965, p. 49) declara que "o 'cenário' possui uma significação autônoma, enquanto elemento destinado a completar o ambiente". Tomada desta perspectiva, a estante da sala do delegado, em Inferno provisório, tem muito a dizer sobre o contexto no qual os fatos narrados transcorrem. Ela é indicativa do modo como o aparelho do estado toma o conhecimento. Qual seja: como instrumento de empoderamento e de resguardo de suas práticas abusivas.

Mesmo que o foco recaia sobre o proprietário do circo, o narrador demonstra-se atento a tudo e a todos ao seu entorno. Daí estarem atreladas, em seu discurso, as descrições do espaço e do ambiente da delegacia ao tratar, por exemplo, dos personagens que aguardam na recepção. Dessa forma, o cenário é preenchido pela mulher acomodada no "sofá furta-cor, molas expostas" que espera o filho "tirar a carteira de identidade"; pelas duas mulheres que se estranharam "por causa de homem, segundo o plantonista que subscrevera o BO", por "um retireiro" que "repassava o sumiço de um leitão de cria" e pelo bêbado que se encontrava "no chão, de coque" (RUFFATO, 2016, p. 182). 

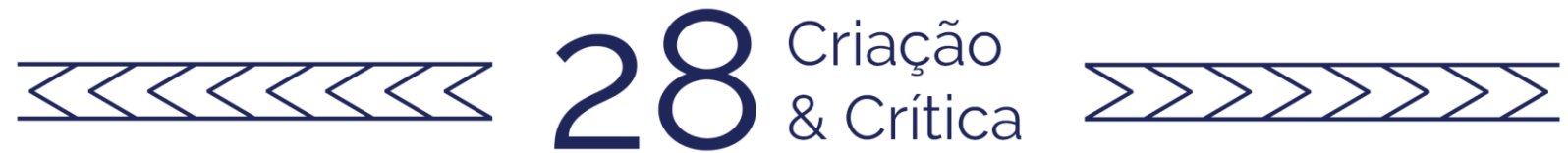

Apesar de não ser mencionado pelo narrador, tudo indica que ele tenha testemunhado os fatos na função de estagiário d'O Cataguases. É possível que tenha se deslocado até a delegacia, seguindo ordens do editor-chefe, para sondar as notícias ou buscar alguma 'nota', visto que, naquele momento, Luís Augusto não tinha nenhum tipo de autonomia para redigir as notícias publicadas no jornal. Autonomia que tem no presente da enunciação, quando narra os fatos desde a perspectiva de quem ele era no tempo em que os testemunhara e, por conseguinte, de quem se tornou.

Há um movimento político de desvelamento das engrenagens de poder do Estado no discurso do narrador sem, contudo, ser acusatório. Nada é declarado, mas muitas são as evidências que levam o leitor ao questionamento sobre a interferência do órgão policial no crime que ceifou a vida do proprietário do circo. Tudo isso por intermédio de um discurso sutil que põe em xeque a índole do delegado, sempre submetido aos mandos dos verdadeiros "donos dos porcos". O narrador não é mais o garoto ingênuo de outrora. No tempo em que narra é capaz de denunciar as mazelas do período da ditadura militar por meio de um realismo cru que ascende a uma linguagem metafórica.

Prova disso está na escolha de um estilo que se casa muito bem com o conteúdo e com o contexto da ditadura militar e da censura à imprensa. A década de 1970 é revisitada por intermédio de um discurso narrativo que atualiza uma estética construída pela aliança entre literatura e reportagem. O último bloco da história constitui-se unicamente de uma matéria de jornal intitulada Crime de Homicídio. Nela é relatado o homicídio do "proprietário de circo" e mencionada a conclusão do inquérito pelo delegado. Havendo, portanto, circulado entre os citadinos que o crime transcorrera

[...] por 'motivos fúteis' já que o criminoso, visivelmente embriagado, segundo testemunhas arroladas, querendo assistir o espetáculo sem pagar, e tendo sido interpelado pela vítima, reagiu [...] (RUFFATO, 2016, p. 185).

A fonte da matéria jornalística é citada ao final da notícia: "(Correio da Cidade Domingo, 16 de maio de 1976, coluna "Ronda policial", p. 4)". Procedência que além de provocar um "efeito de real", é mais um indício da identidade do narrador. A data de circulação da notícia coincide com o período em que Luís Augusto era estagiário do semanário da cidade.

A última 'história' do romance é "OUTRA FÁBULA". A narrativa inicia pela informação do espaço e do tempo no qual se encontra o narrador.

Imerso entre os milhares de calções e camisetas numeradas que, sob o calor de mais de trinta graus, aguardavam impacientes, na tarde do último dia de 2002, em frente ao prédio do Museu de Arte de São Paulo, pela largada da Corrida de São Silvestre, Luís Augusto, alongando os músculos, especulava se conseguiria vencer os quinze quilômetros de subidas e descidas do trajeto. Afinal, quarenta anos cumpridos, catorze meses antes mantinha-se sedentário [...] (RUFFATO, 2016, p. 387). 

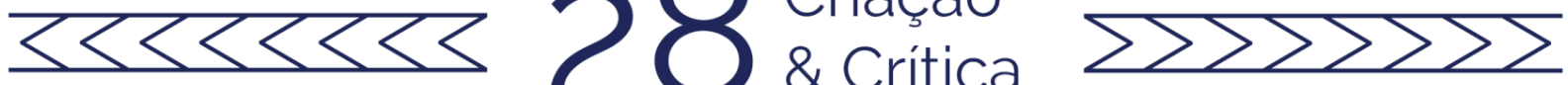

Por meio de analepses o narrador revela que foram os problemas de saúde, intensificados pelo sedentarismo, que o levaram a praticar exercícios físicos e, consequentemente, a decidir participar da corrida na qual se encontra em posição de largada no presente da sua enunciação.

A problemática em torno da identidade do narrador de Inferno provisório parece estar no fato do discurso narrativo ser proferido na terceira pessoa gramatical, mas se revelar enquanto autobiografia ficcional. Este é um dos pontos caros à voz narrativa no romance. O procedimento adotado para a configuração de uma "autobiografia em terceira pessoa" exige certo esclarecimento entre as questões de identidade e de pessoa gramatical. Em outras palavras, a distinção entre o sujeito da enunciação e o sujeito do enunciado ${ }^{3}$.

Pois bem, Luís Augusto é o narrador do romance. Em "OUTRA FÁBULA", além de narrador ele assume o papel de personagem principal. Todavia, essa equivalência torna-se um pouco complexa posto que o discurso é enunciado em terceira pessoa. A retomada de alguns fatos pontuais da vida de Luís Augusto é indispensável para a compreensão de quem ele é quando narra o romance. É, pois, nesta última história que se revelam muitas coisas sobre a sua existência.

Do ponto de vista amoroso, Luís Augusto vinha de um "casamento que se arrastara por intermináveis onze anos" com Lívia e é surpreendido com o pedido de casamento feito pela namorada Milene. Esta personagem tem muito a revelar do ponto de vista das mulheres que permeiam as páginas do romance. Posto que, nas disposições das trinta e oito histórias, Milene ocupa um lugar sociocultural que requer atenção. Sua própria existência é a metonímia da mulher do início do século XXI. É o contraponto da "menina-Bettio" que o leitor conhecera em "UMA FÁBULA", na primeira história do romance. Como anunciado pelo título, Milene pertence não só a 'outro' universo ficcional, mas também espacial e temporal. Assim como Luís Augusto, para quem é chegado o tempo de narrar.

A proposta de casamento lançada pela namorada e acompanhada das vantagens advindas do empreendimento, inquieta o narrador-personagem que se encontrava desesperançado com esse tipo de compromisso. A trajetória da vida conjugal é, então, retomada tanto pela sua própria perspectiva, quanto pela perspectiva da ex-mulher. Ela, também jornalista, sofreu para conciliar a vida profissional com a maternidade. Viu-se obrigada a abdicar de melhores postos no mercado de trabalho e submeter-se às revisões mal pagas. Lívia via o marido como uma pessoa conformada com trabalhos que resultavam em baixo rendimento. Incomodava-a também a cautela de Luís Augusto para assumir compromissos financeiros. O que a distanciava, cada vez mais, dos bens de consumo com os quais tanto sonhava: uma "viagem à Europa", "férias no Nordeste", "um apartamento maior", a "troca dos móveis".

\footnotetext{
${ }^{3}$ Sobre o assunto, consultar o quadro elaborado por Lejeune $(2014$, p. 21) que trata sobre a pessoa gramatical e identidade.
} 

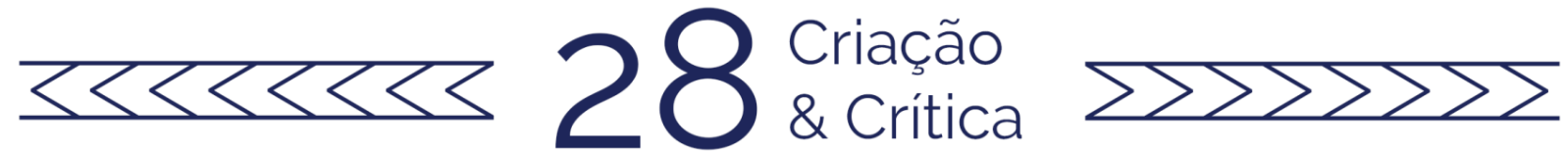

Mas aquilo que para Lívia era motivo de insatisfação, para Luís Augusto era de orgulho. Constatação advinda de suas reflexões sobre o presente tendo como parâmetro o passado. Mesmo com os contratempos, o narrador-personagem "julgava poder orgulhar-se do caminho percorrido", pois, há vinte anos, era "Uma camisa desembarcando, zonza, na rodoviária da Luz" (RUFFATO, 2016, p. 388).

O artigo indefinido que acompanha o substantivo "camisa", representando, metonimicamente, o próprio personagem-narrador, contribui para o efeito de perda de individualidade. Absorvido pela multidão, ao desembarcar na rodoviária de São Paulo, Luís Augusto viu-se sozinho. Tal como se encontra no presente da enunciação: imerso em uma multidão de desconhecidos.

Enquanto Luís Augusto aguarda o sinal de largada, em inércia, sem que seu corpo sofra qualquer variação de velocidade, as memórias o transpõem, pelo 'túnel do tempo', a um passado familiar. De onde fluem lembranças que colaboram para recompor sua história de vida e as histórias daqueles que dela participaram.

Se há vinte anos era uma camisa dentre centenas que circulavam pela rodoviária de São Paulo; no presente de sua enunciação, é um número dentre milhares que diferenciam as camisetas e os calções dos corredores. A metonímia, substituído o possuidor pelo possuído, construída por intermédio de um trabalho de rememoração provoca um efeito estético muito caro ao romance, qual seja: o sentimento de não pertencimento que acompanha o migrante por toda a vida.

Inferno Provisório lança-se como experimentação literária que põe em tensão categorias tradicionais da narrativa e, com a voz da enunciação não é diferente. Em "OUTRA FÁBULA", Luís Augusto encontra-se na posição de narrador e de personagem principal instaurando uma intricada relação entre essas entidades fictícias.

No quesito gramatical, quanto ao emprego da primeira pessoa, Gérard Genette (1979) classifica a narrativa em "autodiegética" quando há identidade entre o narrador e o personagem principal e em "homodiegética" quando não há identidade entre essas duas entidades. Em Inferno provisório constata-se a técnica de uma narrativa ficcional enunciada por um narrador que se constitui pelo seu papel de personagem da ficção. A voz narrativa de Luís Augusto, quando enunciada, suscita diversos efeitos advindos de uma técnica de escrita "autobiográfica", na voz gramatical de uma terceira pessoa. Dentre eles sobressai a competência para narrar advinda da sensibilidade com a qual exerce seu papel primeiro, o de membro de uma comunidade.

Retornemos à história "Era uma vez", agora sim para tratar das sobreposições de fatos, datas e personagens. A fábula narra a ocasião em que Luís Augusto reencontrara Nílson Groppo no exercício da função de segurança do Mappi. Apesar de não se apresentar ao "antigo camarada", o sobrenome no crachá põe-se diante dele como porta de acesso a uma semana de julho, de 1976. Trata-se da ocasião em que Luís Augusto acompanhou o pai a São Paulo para uma visita ao irmão. Seu Raul deixara o filho adolescente na casa dos padrinhos e seguira, sozinho, à casa do irmão que morava em São Bernardo. Período em que Luís Augusto convivera com o então segurança, o mesmo "Nílson de quinze anos menos", irmão de Natália, filhos de Nelly que, por sua vez, é filha 

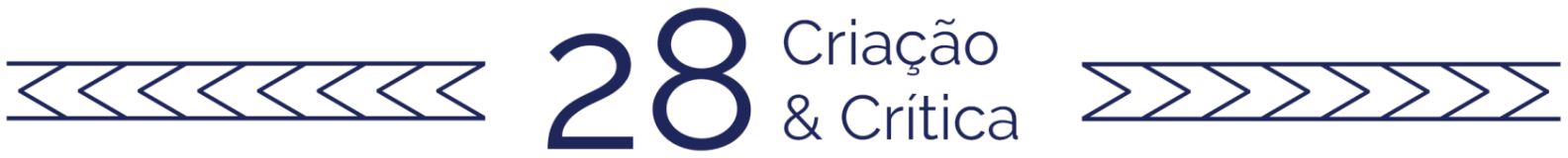

de Alzira e Olegário, os padrinhos de Luís Augusto. O casal morava sob a laje de Nelly, a filha que os arrancara de Cataguases. Além desse núcleo familiar, outros personagens são trazidos à baila por intermédio das memórias do narrador. Dentre os quais estão Indiara, a funcionária da casa, Wil, o namorado de Natália, os garotos que pertenciam à turma do Nilson.

Em "Era uma vez", o tempo da história é indicado pelas referências estabelecidas com a viagem de 1976. Posto que Luís Augusto depara-se com Nílson quinze anos depois da viagem, deduz-se que o primeiro bloco narrado, desta história, transcorrera em 1991. No entrecruzamento de "Era uma vez" e "OUTRA FÁULA", muitas das datas sobrepõem-se e avultam-se pontos de confluência que revelam o narrador em vários momentos de sua trajetória. Luís Augusto nasce em 1961; em 1972 é "um menino tímido, pasmado, esquadrinhando as ruas de Cataguases, nos braços um tabuleiro de alumínio" (RUFFATO, 2016, p. 388); Na adolescência, em 1976, a viagem para São Paulo e a estadia na casa dos padrinhos. Experiência determinante para o seu destino, posto que seis anos depois decide deixar Cataguases e tentar a vida na grande São Paulo. Seu Raul, que retornara a Cataguases convicto de que o irmão Juca havia se dado bem em São Paulo - possuía "casa própria", "carro na garagem" e "filhos estudados" -, declarava, repetidamente, "São Paulo é um mundo". A princípio a frase soava como conselho ao caçula para não seguir o mesmo caminho que os irmãos e acabar trabalhando para os Pratas. Estes eram os maiores proprietários de bens e de meios de produções da cidade. Em 1982, Luís Augusto era "uma camiseta desembarcando, zonza, na rodoviária da Luz" (RUFFATO, 2016, p. 388). Em "OUTRA FÁBULA", o narrador-personagem discorre também sobre suas raras idas à Cataguases e escassos telefonemas, os percalços da vida conjugal, a chegada dos filhos, o divórcio. Os marcos temporais que enquadram a história de Luís Augusto são triviais diante da complexidade das sobreposições temporais que fluem do seu discurso num devir irrefreável. Todavia, eles corroboram o desvelamento da sua identidade enquanto o narrador do romance.

Cerqueira (2014) supõe uma relação entre o personagem Luís Augusto e o autor da série Inferno Provisório em que o primeiro seria a representação do segundo. Ele declara que:

[...] a relação entre a - provável - escrita do Inferno provisório por Luís Augusto e a própria conclusão da pentalogia podem ser base para reflexões que ajudem a esmiuçar as movimentações de Luiz Ruffato no campo literário e para as quais importam tanto o protocolo de leitura quanto a autoimagem com que ele transita nesse espaço particular (CERQUEIRA, 2014, p. 221).

Nesta passagem, nota-se certa obliteração em relação aos papéis do escritor e do narrador. Cerqueira percebe um diferencial na maneira como Luís Augusto ocupa as páginas de Inferno provisório. No entanto, sua atenção volta-se mais para o que ele chama de "alter ego do autor" do que para a identidade do narrador propriamente dita, ou 

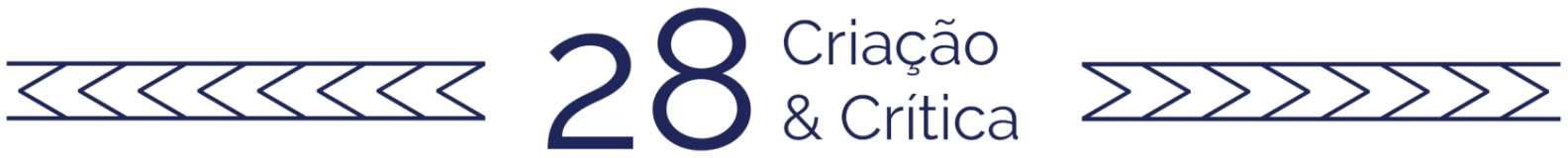

seja, do narrador enquanto ser de papel, enquanto entidade ficcional que organiza e anuncia o mundo fabular.

Sobre as reformulações que Ruffato executa nas obras Histórias de remorsos e rancores (1998) e (os sobreviventes) (2000) para integrá-las ao projeto Inferno Provisório, Lísias, em seu artigo Sem compasso - Notas sobre a obra de Luiz Ruffato, indica um suposto "descompasso entre um narrador" e "sua tentativa de reproduzir uma linguagem que seria presumivelmente a das classes mais baixas". No trecho supracitado, o ensaísta refere-se à entidade responsável pela enunciação de "Sulfato de morfina". Portanto, ele não capta a figura do narrador de Inferno Provisório. Ao ampliar o horizonte de leitura para os dois primeiros volumes da série, Lísias assegura:

[...] O choque termina deixando os textos com uma impressão de descompasso, cuja consequência mais grave é a dificuldade para que o discurso se solidifique formalmente. O leitor acaba sempre pressentindo alguma fraqueza nos narradores de Ruffato: resta a impressão de algo desconjuntado (LíSIAS, 2014).

Sobre as considerações do ensaísta, dois pontos merecem ressalvas. Primeiro, há uma errônea percepção de que várias entidades narram as histórias de Inferno Provisório. Segundo, o que Lísias trata por "descompasso" merece uma investigação atenta do ponto de vista da identidade do narrador. Em outras palavras, na tomada dos (re)arranjos vocabulares deve-se, pois, considerar a perspectiva daquele que é o responsável pela enunciação. Ainda que o projeto literário de Ruffato estivesse inconcluso, se é que este termo possa ser empregado, no momento em que fora lido por Lísias, a existência do narrador-personagem já estava instaurada. Luís Augusto encontrase nos dois primeiros volumes de Inferno Provisório enunciando os fatos, mas também transitando nos espaços da diégese. Isso acontece, por exemplo, em "O segredo", como demonstrado no início deste trabalho. História que é, inclusive, citada por Lísias no referido estudo.

As questões em torno do narrador de Inferno provisório que têm inquietado uma parcela do público leitor, também foi motivo de inquietação para o próprio escritor. Em uma entrevista informal, ao questioná-lo sobre a manutenção das posições das histórias "UMA FÁBULA" e "OUTRA FÁBULA", quando da reedição do volume único de Inferno Provisório, Ruffato respondera:

Nesse volume único eu tentei dar um sentido mais cronológico para as histórias. Que já tinha nos outros cinco volumes. Mas, não era muito claro. No volume único ele é mais objetivo. Quer dizer, há um sentido temporal mais claro. Mas, dois momentos estavam fora dessa cronologia. Um é o que eu chamo de prólogo, que é Uma fábula. Ela funciona como uma espécie de criação do mundo. Uma espécie de gênesis. Porque ali tem uma génese, quer dizer, alguém que cria o mundo inteiro a partir do absolutamente nada. Como Deus fez. Então aquilo é um prólogo que está fora do tempo. E o epílogo também está fora do tempo. O que é mais complicado. Por que ele está fora do tempo? Ele talvez seja o momento 

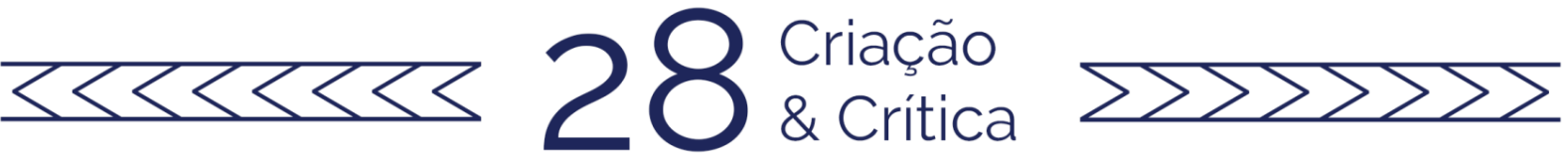

em que... pelo menos eu, enquanto escritor, me dei conta de que ele era quase que a justificativa do livro inteiro. É como se eu descobrisse ali quem era o narrador do livro inteiro. O narrador do livro inteiro está ali. E ele é, inclusive, exacerbado ao longo do romance. Nos volumes, separadamente, não fica claro, mas no volume único acho que fica claro quem é o narrador. Único. Então, assim, o narrador único está no epílogo porque o epílogo também está fora do tempo. Porque ali você descobre afinal de contas quem que faz essa ponte entre géneses e apocalipse. No caso, quem está no começo e no fim ali e que junta tudo. A ideia foi exatamente isso. Então eu reorganizei para ficar mais cronológico (RUFFATO, 2019 - Grifo nosso) ${ }^{4}$.

Mantê-las na mesma posição além de garantir o status de princípio e de fim dentro do universo romanesco, é uma maneira de reforçar o lugar do narrador, como declarou o próprio Ruffato. Todavia, como já mencionado, o escritor não nega a ciência da identidade do narrador do romance antes da última história. O que ele faz é salientar que essa identidade deixa-se revelar ao final, ou seja, em "OUTRA FÁBULA". Para chegar a esta formulação o escritor coloca-se na posição do leitor, compartilhando com este a sensação experienciada da revelação da identidade do narrador. Ao declarar "é como se eu descobrisse ali quem era o narrador do livro inteiro", Ruffato dá uma pista ao leitor sobre onde buscar a identidade dessa personalidade ficcional.

Realmente, essa figura que perpassa as trinta e oito histórias que constituem o romance deixa sua presença transparecer sutilmente. Na versão seriada ela parece fluidificar-se ainda mais. Evidentemente que as inúmeras facetas assumidas pelo narrador tornam sua identidade mais obscura, exigindo do leitor atentas (re)leituras. Luís Augusto apresenta-se, ora como narrador homodiegético ( $\mathrm{O}$ segredo), ora autodiegético ( $\mathrm{O}$ ataque), quando não heterodiegético (Aquele profundo silêncio das manhãs de domingo).

\section{Algumas considerações}

Uma varredura, insubordinada à ordem sequencial das histórias ou cronológica dos fatos, com paradas em excertos que revelam a identidade do narrador, foi o percurso adotado nesta pesquisa. Um aporte teórico consistente auxiliou-nos nesta leitura sobre a identidade do narrador de Inferno provisório.

Com seu caráter experimental, próprio da prosa de ficção contemporânea, o romance lida com uma grande diversidade de gêneros textuais e não deixa de fora a autobiografia. A questão é que esse gênero não se apresenta em sua forma mais corriqueira de autobiografia clássica, aquela em primeira pessoa em que há identidade entre o narrador, o personagem principal e o autor.

A alta capacidade de reflexão do narrador leva-o a assumir um distanciamento em relação ao personagem que foi $e$ isso influencia na sua escolha pela forma narrativa

\footnotetext{
${ }^{4}$ As citações do autor foram colhidas pela autora deste artigo, em entrevista pessoal, realizada na noite de 12 de junho de 2019, em Tangará da Serra-MT.
} 

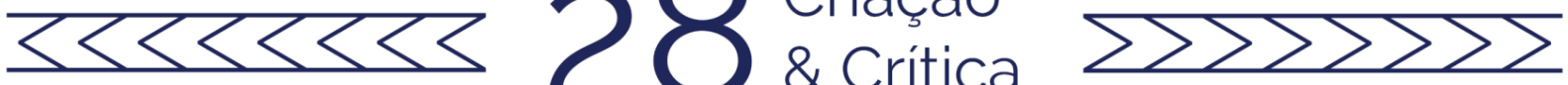

autobiográfica em terceira pessoa. Inferno provisório não é uma autobiografia, posto que não há identidade de nome entre o autor, o narrador e a pessoa de quem se fala. Luís Augusto é uma pessoa fictícia, que assume o papel de narrador e, enquanto tal, explana inúmeros eventos nos quais uma gama de personagens se entrelaça. $O$ que há de autobiográfico no romance é o estilo assumido pelo narrador e que toma corpo na última história. Nela, a técnica autobiográfica presta-se ao esclarecimento sobre o conhecimento dos fatos narrados e não à declaração de correspondência identitária entre autornarrador-personagem, como sugere Cerqueira (2016).

A solidão torna-se a companheira do migrante. Na rodoviária de São Paulo, em meio ao "frenético ir e vir das gentes apressadas", Luís Augusto teve medo, mas resistiu e seguiu pela noite "antecipando a solidão a que se condenara" (RUFFATO, 2016, p. 392). Condenação esta reafirmada no tempo presente, quando se encontra em meio a uma multidão de corredores focados, cada qual, em suas próprias metas.

Ao chegar em São Paulo, na condição de migrante, Luís Augusto não procurou pelos conhecidos porque havia tomado uma decisão, a de "romper em definitivo com seu passado" (RUFFATO, 2016, p. 382). Todavia, não consegue desvencilhar-se do seu legado que é o de narrar. Ainda que supunha haver abandonado o passado, o passado não o abandonara, como se constata nas últimas palavras enunciadas:

Imerso entre milhares de calções e camisetas numeradas, sob um calor de mais de trinta graus, aguardando o sinal para o início da largada da Corrida de São Silvestre, na tarde do último dia de 2002, tudo isso Luís Augusto buscava esquecer (RUFFATO, 2016, p. 406).

O caminho para se esquecer o passado é lembrá-lo. A largada da corrida alegoricamente supõe o início de uma 'nova' trajetória de vida depois de cumprida a tarefa de narrar o passado. Todavia, Luís Augusto desconhece o futuro, ou seja, os caminhos que trilharia após a largada desse novo tempo.

Por que Luiz Ruffato não deixa explícito a identidade do narrador no transcurso do romance? Provavelmente por não caber em seu projeto um narrador soberano, unilateral e mesmo autoritário, que sobrepusesse o seu discurso aos demais. Ele narra não somente por ele, ainda que isso pese sobre seus ombros, mas pelos inúmeros personagens sobre os quais seu discurso lança holofotes, sem os quais, desapareceriam no esquecimento. A incumbência lhe fora dada, pelo destino, por Deus, pelas suas próprias escolhas. O inferno provisório a ele lhe cabe narrar. Pelo menos enquanto esteja em seu estado de provisoriedade.

Quando narra, Luís Augusto encontra-se espacial e temporalmente distante dos acontecimentos; conta com um conhecimento técnico que advém da sua formação acadêmica em jornalismo e também de senso-crítico para interpretar os fatos históricos, políticos e econômicos do país. Portanto, no presente da enunciação, ele está pronto não só para contar, mas também para interpretar um passado que ao mesmo tempo em que Ihe é estranho, é seu. 

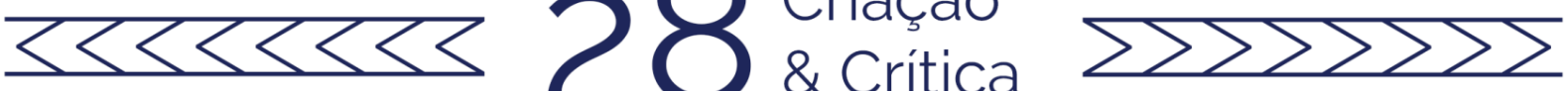

\section{Referências}

AGUIAR, V.; BORDINI, M. Literatura: a formação do leitor: alternativas metodológicas. Porto Alegre: Mercado Aberto, 1993.

CERQUEIRA, R. Um escritor excepcional, uma obra de exceção: o Inferno provisório e as movimentações de Luiz Ruffato no campo literário brasileiro. 2016. 251f. Tese Doutorado - Universidade Federal de Juiz de Fora. Faculdade de Letras. Programa de Pós-graduação em Estudos Literários. Juiz de Fora, 2016.

GENETTE, G. Discurso da narrativa: ensaio de método. Arcádia. Trad. de Fernando Cabral Martins. Lisboa: Arcádia, 1979.

HALBWACHS, M. A Memória Coletiva. Tradução de Beatriz Sidou. São Paulo: Centauro, 2006.

LEJEUNE, P. O pacto autobiográfico: de Rousseau à Internet. Trad. de Jovita M. G. Noronha; Maria Inês C. Guedes. 2 ed. Belo Horizonte: Editora UFMG, 2014.

LíSIAS, R. "Sem compasso - Notas sobre a obra de Luiz Ruffato". In: Intervenções: Álbum de crítica. Coleção Geleia Real. e-galáxia, 2014.

LUKÁCKS, G. Narrar ou descrever? Contribuições para uma discussão sobre o naturalismo e o formalismo. In: Ensaios sobre literatura. Rio de Janeiro: Civilização Brasileira, 1965. p. 43-94.

PELLEGRINE, T. A refração do realismo em Luiz Ruffato: um inferno permanente. Estudo de Literatura Brasileira Contemporânea. Brasília. n. 59, jan./abr. 2020, p. 1-12. Disponível em: <https://periodicos.unb.br/index.php/estudos/article/view/29336>. Acesso em: jun. 2020.

RUFATTO, L. (os sobreviventes). São Paulo: Boitempo, 2000. . Domingo sem Deus. (Inferno Provisório Volue 5). Rio de Janeiro, Record, 2011a. Histórias de remorsos e rancores. São Paulo: Boitempo, 1998.

2005. Mamma, son tanto felice. (Inferno Provisório Volume 1). Rio de Janeiro: Record, Record, 2008.

O livro das impossibilidades. (Inferno Provisório Volume 4). Rio de Janeiro, . O mundo inimigo. (Inferno Provisório Volume 2). Rio de Janeiro, Record, 2005. 2006a. Vista parcial da noite. (Inferno Provisório Volume 3). Rio de Janeiro, Record,

"Viver de literatura". In: RUFFATO, Luiz. Minha primeira vez. Porto Alegre: Arquipélago editorial: 2014. p.177-180.

. Entrevista concedida ao Programa Entrelinhas, Arte e Cultura, da TV Cultura. 13/11/2011b. Disponível em: <https://tvcultura.com.br/videos/8897_luiz-ruffatoentrelinhas-13-11-2011.html>. Acesso em: 26 mai. 2020.

. Inferno provisório. São Paulo: Companhia das Letras, 2016.

Literatura com um projeto. Entrevista concedida a Heloísa Buarque de Hollanda e Ana Lígia Matos. Revista Z Cultural. Rio de Janeiro, ano III, n. 01, 10 de mar., 2006b. 

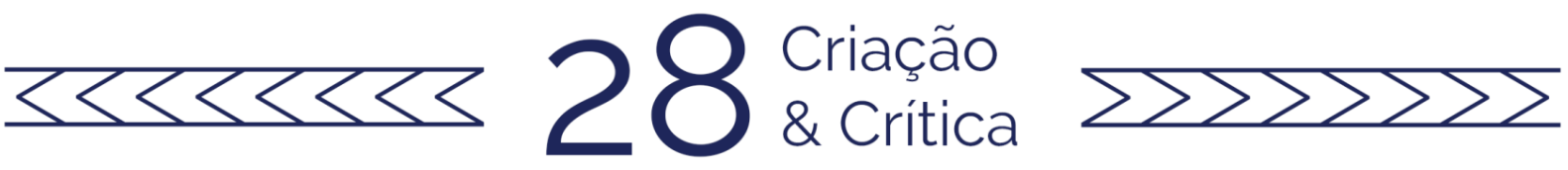

Disponível em: <http://revistazcultural.pacc.ufrj.br/literatura-com-um-projeto-entrevistacom-heloisa-buarque-de-holanda/>. Acesso em: 23 out. 2019.

VIEIRA, M. Formas mínimas: minificção e literatura brasileira contemporânea. 2012. Tese - Doutorado em Letras - Centro de Letras e Ciências Humanas, Programa de PósGraduação em Letras, Universidade Estadual de Londrina, Londrina, 2012.

Recebido em: 10/07/2020

Aceito em: 10/11/2020

Referência eletrônica: DA SILVA, Daniele Cristina. As faces do narrador em Inferno Provisório, de Luiz Ruffato. Criação \& Crítica, n. 28, p., dez. 2020. Disponível em: $<$ http://revistas.usp.br/criacaoecritica>. Acesso em: dd mmm. aaaa. 